\title{
Analisis Prioritas Perbaikan Sistem Kerja Industri Rumah Tangga dengan Program WISH
}

\author{
Luciana Triani Dewi ${ }^{1 *}$, Chandra Dewi $\mathrm{K}^{2}$ \\ 1*,2) Fakultas Teknologi Industri, Program Studi Teknik Industri, \\ Universitas Atma Jaya Yogyakarta \\ Jl. Babarsari No. 43, Yogyakarta 55281 \\ email : triani.dewi@mail.uajy.ac.id, candra@mail.uajy.ac.id
}

\begin{abstract}
The purpose of this paper is to analyze work system improvements of home industries in Yogyakarta City, based on participatory ergonomics approach. WISH (Work Improvement for Safe Home) action checklist has been used as the instrument to analyse and evaluate the working conditions. WISH programme is an action manual published by ILO (International Labour Organization) to improve work conditions of home manufacturing by using a participatory approach. The working conditions in WISH action checklist covers five aspects; i.e. materials storage and handling, machine safety, work stations, physical environment, and welfare facilities and work organization. The early step in this study was identification of general characteristics of home industries in Yogyakarta City. The results of identification were used as input in developing improvement actions. Analysis was done to determine the priority among all improvement aspects and improvement actions based on WISH action checklist. The findings show the most priority aspect of improvement was Work Stations aspects with index priority 0.172. The action needed for the most priority improvement aspect was developed by consideration of home industries characteristics.
\end{abstract}

Keywords: work system, work improvement, participatory, home industry, WISH

\begin{abstract}
Abstrak
Makalah ini membahas tentang analisis aspek perbaikan sistem kerja industri rumah tangga di Kota Yogyakarta dengan pendekatan ergonomi partisipasi. Analisis dan evaluasi kondisi kerja dilakukan dengan menggunakan instrumen daftar periksa tindakan WISH (Work Improvement for Safe Home). Program WISH merupakan suatu manual yang dipublikasikan oleh ILO (International Labour Organization) untuk melakukan tindakan perbaikan kondisi kerja dengan pendekatan ergonomi partisipasi untuk industri skala rumah tangga (home manufacturing). Aspek kondisi kerja yang dievaluasi meliputi (1) penyimpanan dan penanganan material, (2) keselamatan mesin, (3) stasiun kerja, (4) lingkungan fisik, dan (5) fasilitas kesejahteraan dan organisasi kerja. Sebagai langkah awal dilakukan identifikasi karakteristik umum industri rumah tangga di Kota Yogyakarta. Hasil identifikasi digunakan sebagai input dalam mengembangkan langkah-langkah perbaikan. Analisis dilakukan untuk menentukan prioritas aspek dan langkah-langkah perbaikan berdasarkan evaluasi daftar periksa tindakan WISH di sejumlah industri rumah tangga. Hasil yang diperoleh menunjukkan aspek Stasiun Kerja sebagai prioritas utama perbaikan dengan indeks prioritas 0,172. Langkah-langkah perbaikan untuk aspek prioritas dikembangkan dengan memperhatikan karakteristik industri rumah tangga.
\end{abstract}

Kata Kunci: sistem kerja, perbaikan kerja, partisipasi, industri rumah tangga, WISH

\section{Pendahuluan}

Menurut Badan Pusat Statistik (BPS), industri rumah tangga (IRT) merupakan industri dengan

\footnotetext{
*Korespondensi Penulis
}

jumlah tenaga kerja kurang dari 5 (lima) orang (BPS, 2012). Karakteristik utama dari industri rumah tangga adalah sebagian besar pekerjanya merupakan anggota keluarga dari pemilik usaha serta proses produksi dijalankan secara 
manual dan hanya dilakukan di rumah.

Peran industri skala mikro semacam ini tidak dapat dikesampingkan dalam perekonomian Kota Yogyakarta. Sampai dengan tahun 2012 terdata sebanyak 4545 industri mikro kecil dan menegah di Kota Yogyakarta (http://umkm.jogjakota.go.id/direktori/index. php 2013). Dari jumlah tersebut, industri mikro atau industri rumah tangga jumlahnya mencapai 2735 (Wibowo 2012) meliputi industri jasa, manufaktur dan distribusi. Potensi industri rumah tangga memberi kontribusi signifikan bagi perekonomian masyarakat. Oleh karena itu perlu didorong dan dikembangkan agar dapat menjadi pelaku industri yang tangguh meskipun dalam skala rumahan. Terlebih bagi Kota Yogyakarta, dimana jumlah IRT di wilayah ini cukup signifikan. Berbeda dengan daerah lain di DIY yang masih bisa mengandalkan lahan pertanian atau perkebunan, wilayah Kota Yogyakarta lebih mengandalkan industri rumah tangga untuk perekonomian masyarakat dan mengurangi pengangguran.

Tempat kerja merupakan salah satu aspek penting yang perlu diperhatikan dalam perbaikan industri rumah tangga. Tempat kerja (workplace) didefinisikan sebagai sebuah ekosistem yang terdiri dari manusia, proses dan tempat yang dikembangkan untuk memberi dukungan bagi manusia dan lingkungan kerjanya. Strategi tempat kerja yang inovatif akan memberi dampak pada optimisasi performansi bisnis (Mitchell-Ketzes, 2003). Perbaikan tempat kerja akan memberi kontribusi penting bagi produktivitas, kualitas dan kesehatan serta moral pekerja (Petrarolo 1998 ; Grant, et al. 2003 ; Harte, et al. 2011). Sebaliknya, ada berbagai kondisi kerja yang akan berdampak negatif bagi tempat kerja seperti: depresi karyawan (Edlin, 2006), merokok (Anonymous, 2001) dan gender (Guy, 1993).

Beberapa studi terdahulu menggunakan bermacam pendekatan dalam perbaikan tempat kerja. Selama bertahun-tahun organisasi telah menerapkan berbagai pendekatan dalam perbaikan tempat kerja, seperti pengendalian kualitas, aktivitas kelompok (team activities) dan reduksi aktivitas setup (Petrarolo, 1998). Salah satu strategi perbaikan tempat kerja adalah dengan menggunakan sistem balanced scorecard yang dapat mengintegrasikan tujuan multi dimensi (Bradley, 2002). Konsep Jepang dalam perbaikan tempat kerja adalah metodologi 5S yang merupakan alat analisis proses di tempat kerja (Michalska and Szewieczek 2007). Secara umum pendekatan-pendekatan tersebut lebih menerapkan pendekatan top down dalam implementasinya.

Ergonomi partisipasi merupakan kategori pendekatan bottom-up, dimana pekerja dilibatkan dalam pengambilan keputusan untuk merencanakan dan mengendalikan aktivitas pekerjaan yang mempengaruhi baik proses maupun hasil yang ingin dicapai (Hendrick and Kleiner 2001). Dalam ergonomi partisipasi keterlibatan secara aktif seluruh personel dalam perencanaan dan pengendalian aktivitas pekerjaan mereka dengan pengetahuan dan kemampuan yang cukup yang dapat mempengaruhi baik proses maupun hasil yang ingin dicapai. Kepercayaan, komitmen dan niat baik dari karyawan akan dihasilkan dari proses partisipasi sehingga dapat meningkatkan kepuasan dan menurunkan kesalahan. Efek tersebut lebih lanjut akan menghasilkan peningkatan performansi (Brown 2002).

Studi yang dilakukan bertujuan untuk melakukan identifikasi karakteristik umum IRT dan menentukan prioritas aspek perbaikan kerja serta mengembangkan tindakan perbaikan sesuai karakteristik industri rumah tangga di Kota Yogyakarta. Hasil studi dapat dimanfaatkan dalam pengembangan strategi perbaikan IRT bagi pemerintah. Pendekatan partisipasi digunakan dalam studi ini dengan menggunakan instrumen program WISH (Work Improvement for Safe Home), yang lebih lanjut dijelaskan pada bagian metode penelitian.

\section{Metodologi}

Studi dilakukan melalui survey di 16 (enam belas) IRT di wilayah Kota Yogyakarta. Industri rumah tangga sebagai objek dalam studi ini adalah jenis industri manufaktur rumahan (home manufacturing), yaitu industri yang memproses bahan menjadi produk dalam skala rumahan. Identifikasi dan analisis terhadap kondisi dan situasi IRT dilakukan pada tahap awal untuk menghasilkan gambaran umum profil IRT di Kota Yogyakarta.

Analisis perbaikan sistem kerja dilakukan dengan menggunakan instrumen daftar periksa WISH. Partisipasi pelaku industri rumah tangga digunakan dalam evaluasi kondisi IRT dan menentukan item pada setiap aspek yang menjadi prioritas untuk dilakukan perbaikan. Pengembangan tindakan perbaikan berdasarkan manual WISH dengan konsep biaya rendah (low cost) dan memanfaatkan sumberdaya yang tersedia. Diagram alir metodologi ditunjukkan pada Gambar 1.

Profil industri rumah tangga diidentifikasi 


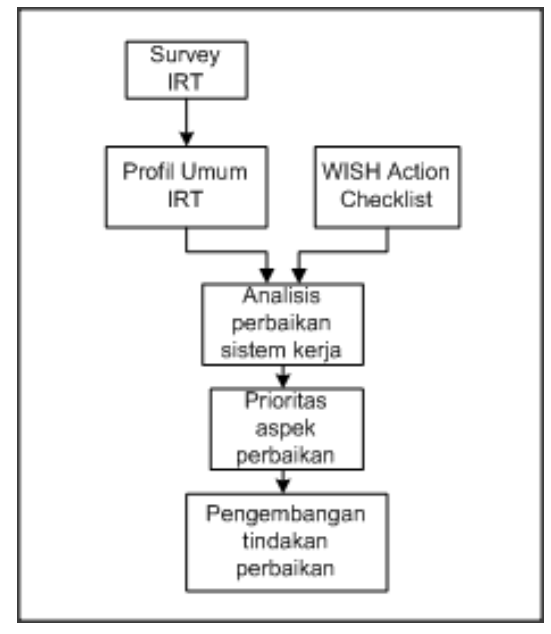

Gambar 1: Metodologi penelitian

berdasarkan 7 (tujuh) parameter karakteristik sebagai berikut:

1. Peran pemilik

2. Lama usaha

3. Waktu kerja

4. Tempat kerja

5. Kondisi alat/fasilitas kerja

6. Kondisi bangunan

Setiap parameter ditentukan atribut yang relevan serta dilakukan dekomposisi setiap atribut dan dikodekan. Daftar atribut, kode parameter dan prevalensi karakteristik ditunjukkan pada Tabel 1.

Tabel 1: Prevalensi Karakteristik IRT Yogyakarta

\begin{tabular}{|c|c|c|c|}
\hline Parameter & Atribut & Kode & Prevalensi \\
\hline \multirow{2}{*}{ Peran pemilik } & $\begin{array}{c}\text { Pemilik ikut sebagai } \\
\text { pekerja }\end{array}$ & A1 & $94 \%$ \\
\cline { 2 - 4 } & $\begin{array}{c}\text { Pemilik tidak sebagai } \\
\text { pekerja }\end{array}$ & A2 & $6 \%$ \\
\hline \multirow{2}{*}{ Lama usaha } & $<10$ tahun & B1 & $31 \%$ \\
\cline { 2 - 4 } & $\geq 10$ tahun & B2 & $69 \%$ \\
\hline \multirow{2}{*}{ Waktu kerja } & Terjadwal rutin & C1 & $37 \%$ \\
\cline { 2 - 4 } & Jadwal kerja fleksibel & C2 & $63 \%$ \\
\hline Tempat kerja & Ada & D11 & $56 \%$ \\
\hline \multirow{2}{*}{ Pengelompokan stasiun kerja } & Tidak ada & D12 & $44 \%$ \\
\cline { 2 - 4 } Pemisahan area kerja dan non kerja & Terpisah & D21 & $56 \%$ \\
\cline { 2 - 4 } & Tidak terpisah & D22 & $44 \%$ \\
\hline \multirow{2}{*}{ Kondisi fasilitas kerja } & Memadai & E1 & $63 \%$ \\
\cline { 2 - 4 } & Terbatas & E2 & $37 \%$ \\
\hline \multirow{2}{*}{ Kondisi bangunan } & Baik & F1 & $75 \%$ \\
\cline { 2 - 4 } & Buruk & F2 & $25 \%$ \\
\hline Lingkungan kerja fisik & Nyaman & G11 & $100 \%$ \\
\hline \multirow{2}{*}{ Suhu } & Tidak nyaman & G12 & $0 \%$ \\
\hline \multirow{2}{*}{ Kebisingan } & Normal & G21 & $100 \%$ \\
\cline { 2 - 4 } & Tidak normal & G22 & $0 \%$ \\
\hline
\end{tabular}

\section{Manual WISH}

Daftar periksa tindakan perbaikan WISH digunakan sebagai instrumen untuk melakukan analisis kondisi kerja dengan pendekatan partisipasi. Berdasarkan hasil dari daftar periksa tindakan WISH, selanjutnya dapat dilakukan analisis prioritas aspek perbaikan dan dikembangkan tindakan-tindakan perbaikan.

WISH merupakan suatu manual yang dipublikasikan oleh ILO (International Labour Organization) untuk melakukan tindakan perbaikan kondisi kerja dengan pendekatan ergonomi partisipasi di industri rumah tangga. Fokus dalam manual ini adalah untuk mencapai kondisi yang sehat dan aman bagi pekerja industri rumah tangga meskipun tempat kerja di rumah (home manufacturing) dan pada umumnya dengan kondisi minimum. Manual ini telah diteliti dan dikembangkan implementasinya di Kamboja, Mongolia dan Thailand (Kawakami dkk., 2006).

Kondisi kerja yang dievaluasi dalam WISH meliputi 5 (lima) aspek, yaitu: (1) penyimpanan dan penanganan material, (2) keselamatan mesin, (3) stasiun kerja, (4) lingkungan fisik, dan (5) fasilitas kesejahteraan dan organisasi kerja. Instrumen evaluasi kondisi kerja WISH berupa daftar periksa tindakan untuk setiap aspek. Keseluruhan terdiri dari 30 (tiga puluh) butir pemeriksaan. Dari setiap butir pemeriksaan, diberikan pertanyaan "Apakah anda mengusulkan perbaikan?". Di bawah pertanyaan tersebut terdapat tiga opsi jawaban, yaitu: 'Ya', 'Tidak' dan 'Prioritas'. Di baris berikutnya diberikan ruang untuk komentar. Pada bagian akhir dari manual WISH, untuk setiap aspek dilengkapi dengan deskripsi mengenai manfaat bagi pekerja, bagaimana cara melakukan perbaikan, cara meningkatkan kerjasama dengan pekerja dalam implementasi perbaikan serta beberapa petunjuk untuk mencapai keberhasilan dalam perbaikan. Deskripsi dilengkapi pula dengan gambar ilustrasi untuk membantu dalam evaluasi dan perbaikan.

\section{Hasil dan Pembahasan}

Hasil pemeriksaan butir WISH berdasarkan observasi pada IRT ditunjukkan pada Tabel 2. $\mathrm{Y} / \mathrm{N} / \mathrm{P}$ menunjukkan hasil identifikasi setiap butir, dimana $\mathrm{Y}=$ Yes (ya), $\mathrm{N}=$ No (tidak) dan $\mathrm{P}=$ Priority (prioritas). Sedangkan $\mathrm{n}$ menunjukkan prevalensi jumlah IRT dan \% menunjukkan prosentase prevalensi.

Indeks prioritas perbaikan dihitung berdasarkan hasil rekapitulasi pengisian daftar periksa WISH Tabel 2. Perhitungan indeks prioritas dilakukan untuk setiap aspek perbaikan dengan cara menghitung rasio antara jumlah item prioritas dengan jumlah butir dikalikan 
jumlah sampel observasi. Indeks prioritas menunjukkan tingkat besaran prioritas perbaikan untuk setiap aspek WISH. Semakin tinggi angka indeks menunjukkan tingkat prioritas perbaikan yang lebih diutamakan. Sebaliknya, semakin rendah angka indeks maka level prioritas perbaikan semakin rendah (semakin tidak diprioritaskan untuk diperbaiki).

\section{Tabel 2: Hasil Pemeriksaan Tindakan WISH}

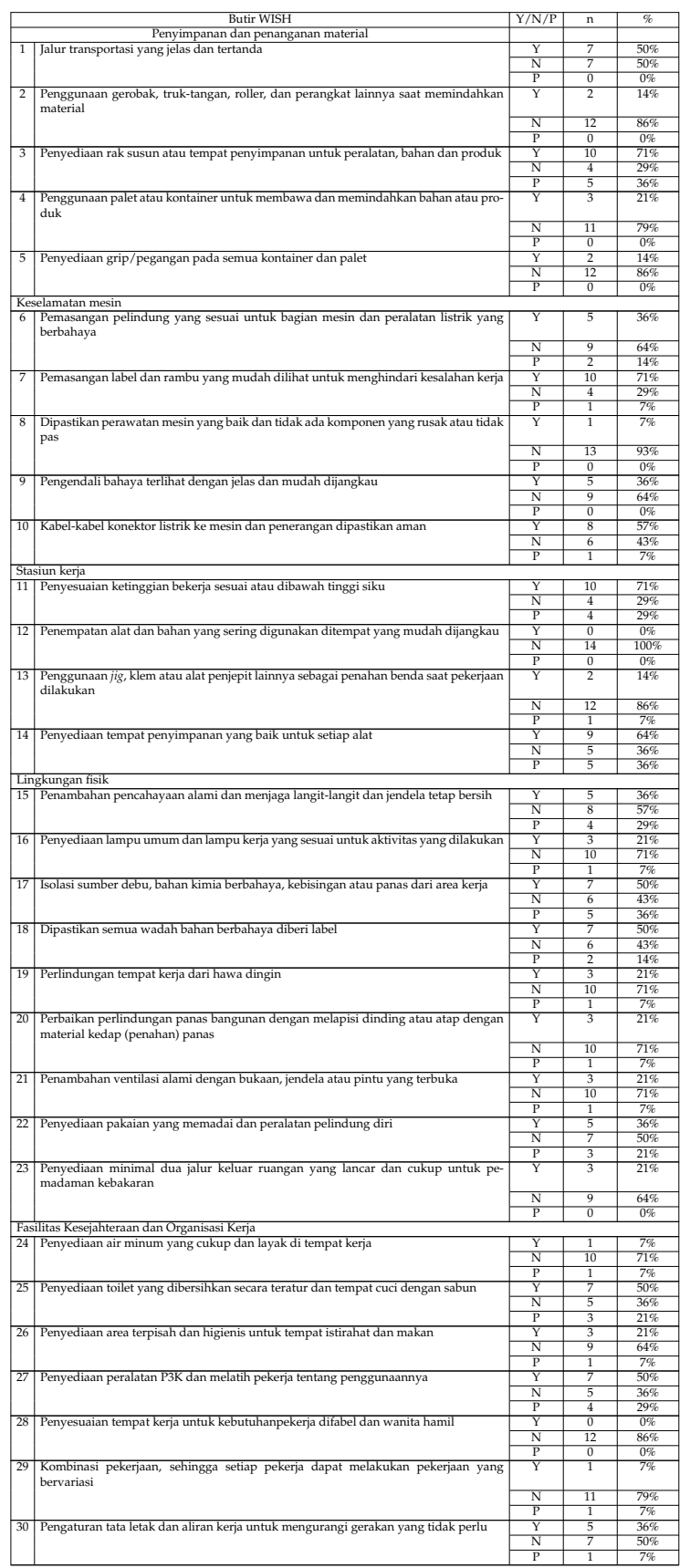

Gambar 2. menunjukkan diagram indeks prioritas dari lima aspek perbaikan dalam daftar periksa WISH. Diagram indeks prioritas perbaikan menunjukkan indeks perbaikan tertinggi adalah untuk aspek 'Stasiun Kerja' dengan nilai indeks 0,172. Hal ini berarti fokus utama prioritas perbaikan kerja IRT Yogyakarta adalah untuk aspek ini. Jika ditinjau kembali hasil butir-butir pemeriksaan WISH Tabel 2, menunjukkan prosentase jawaban 'ya' untuk kebutuhan perbaikan tertinggi (71\%) adalah untuk butir ke-3 yaitu 'penyediaan rak susun atau tempat penyimpanan untuk peralatan, bahan dan produk'. Demikian juga prevalensi prioritas tertinggi $(36 \%)$ ditunjukkan untuk butir tersebut.

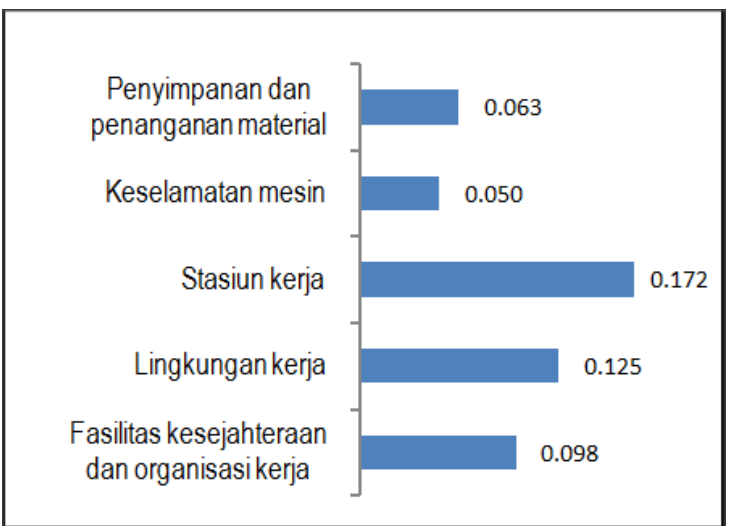

Gambar 2: Indeks Prioritas Aspek Perbaikan Berdasarkan WISH

Pengembangan langkah-langkah tindakan perbaikan untuk butir prioritas dilakukan berdasarkan manual program WISH dengan memperhatikan karakteristik umum IRT yang telah teridentifikasi. Pengembangan langkah tindakan perbaikan ditunjukkan pada Tabel 3. Dalam penerapannya, pemilik IRT yang pada umumnya adalah juga sebagai pekerja, secara bersama-sama dengan pekerja lainnya mengusahakan fasilitas stasiun kerja dan tempat penyimpanan alat yang sesuai untuk digunakan. Fasilitas kerja dan tempat penyimpanan alat dirancang dengan menggunakan bahan-bahan yang sederhana, murah dan mudah didapat di sekitar tempat kerja. Misalnya dengan menggunakan kayu-kayu atau logam bekas. Mengingat sebagian IRT tidak melakukan pengelompokkan stasiun kerja dan juga tidak memisahkan antara area kerja dan non-kerja, maka perlu dipertimbangkan pengaturan yang baik dalam penempatan fasilitas kerja dan tempat penyimpanan alat agar penggunaan dapat optimal dan tidak mengganggu aktivitas kehidupan. 
Tabel 3: Pengembangan Tindakan Perbaikan Untuk Butir Prioritas Perbaikan

\begin{tabular}{|l|l|}
\hline Butir Pemeriksaan & Tindakan perbaikan \\
\hline $\begin{array}{l}\text { Penyesuaian ketinggian bek- } \\
\text { erja sesuai atau di bawah } \\
\text { tinggi siku }\end{array}$ & $\begin{array}{l}\text { Sesuaikan ketinggian meja atau } \\
\text { kursi kerja dengan memperhatikan } \\
\text { ketinggian siku } \\
\text { Penyesuaian dapat dilakukan den- } \\
\text { gan menambahkan pengganjal atau } \\
\text { penampang tambahan jika terlalu } \\
\text { tinggi } \\
\text { Jika membeli perabot baru, pastikan } \\
\text { ketinggian siku tidak bermasalah. }\end{array}$ \\
\hline $\begin{array}{l}\text { Penyediaan tempat penyim- } \\
\text { panan yang baik untuk se- } \\
\text { tiap alat }\end{array}$ & $\begin{array}{l}\text { Kumpulkan alat-alat yang berser- } \\
\text { akan, urutkan sesuai penggunaan- } \\
\text { nya. } \\
\text { Buat lemari/rak atau gantungan } \\
\text { Buat pola bentuk alat di tempat } \\
\text { penyimpanan dan berikan label } \\
\text { untuk memudahkan penyimpanan } \\
\text { kembali } \\
\text { Berikan roda pada rak penyimpan } \\
\text { untuk memudahkan pengambilan } \\
\text { alat di tempat kerja dan pengem- } \\
\text { balian kembali ke tempat semula } \\
\text { Untuk alat-alat yang kecil, tem- } \\
\text { patkan pada penampang lebih } \\
\text { dahulu sebelum meletakkan di rak } \\
\text { penyimpan }\end{array}$ \\
\hline
\end{tabular}

\section{Kesimpulan}

Berdasarkan penerapan program WISH diperoleh hasil aspek 'stasiun kerja' merupakan aspek perbaikan utama yang harus diprioritaskan untuk perbaikan sistem kerja industri rumah tangga di Kota Yogyakarta. Tindakan perbaikan untuk aspek 'stasiun kerja' dikembangkan untuk dua butir pemeriksaan, yaitu penyesuaian ketinggian bekerja dan penyediaan tempat penyimpanan alat. Dalam penerapannya, pemilik IRT yang pada umumnya adalah juga sebagai pekerja, secara bersama-sama dengan pekerja lainnya mengusahakan fasilitas stasiun kerja dan tempat penyimpanan alat yang sesuai untuk digunakan. Dengan pendekatan partisipasi, aspek perbaikan sistem kerja diidentifikasi dan dianalisis berdasarkan keterlibatan pemilik dan pekerja industri rumah tangga. Dengan melibatkan pemilik dan pekerja dalam perbaikan, maka langkah-langkah tindakan perbaikan dapat disesuaikan dengan kondisi, keinginan dan harapan IRT.

Kontribusi hasil penelitian ini adalah memberikan pedoman bagi perumus kebijakan terkait perbaikan sistem kerja IRT khususnya di wilayah kota Yogyakarta sehingga perbaikan dapat lebih terstruktur dan terarah dengan lebih fokus pada aspek yang menjadi prioritas perbaikan. Bagi keilmuan ergonomi makro, hasil studi ini bermanfaat sebagai model pembelajaran aplikasi konsep partisipasi dalam perbaikan sistem kerja.

\section{Daftar Pustaka}

Anonymous. (2001, December). Latest Data on How Smoking Affects Workplace Productivity. HR Focus , p. 9.

Bradley, S. J. (2002). What's Working? Briefing and Evaluating Workplace Performance Improvement. Journal of Corporate Real Estate , 4 (2), 150159.

Brown, O. (2002). Macroergonomic Methods: Participation. in H. W. Hendrick, \& B. M. Kleiner, Macroergonomics Theory, Methods and Applications (p. 29). New Jersey: Lawrence Erlbaum Associates Inc.

BPS Yogyakarta.

http://yogyakarta.bps.go.id/. Accessed February 10,2014

Edlin, M. (2006). Depression Can Be A Detriment to Workplace Productivity. Managed Healthcare Executive, 16 (10), 48-50.

Grant, K. A., Garland, J. G., Joachim, T. C., Wallen, A., \& Vital, T. (2003). Achieving Health, Safety, and Performance Improvements through Enhanced Cost Visibility and Workplace Partnership. AIHA Journal, 64 (3), 660-667.

Grant, K. A., Garland, J. G., Joachim, T. C., Wallen, A., \& Vital, T. (2003). Achieving Health, Safety, and Performance Improvements through Enhanced Cost Visibility and Workplace Partnership. AIHA Journal, 64 (5), 660-667.

Guy, M. E. (1993). Workplace Productivity and Gender Issues. Public Administration Review, 53 (3), 279-282.

Harian Jogja. (2012, August 2). Pertumbuhan Industri Mikro di DIY Turun. Accessed April 1, 2013, from http://www.bisnisjateng.com/index.php/2012/08/

Harte, K., Mahieu, K., Mallett, D., Norville, J., \& VanderWerf, S. (2011). Improving Workplace Productivity-It Isn't Just About Reducing Absence. Benefits Quarterly, 27, pp. 13-27.

Hendrick, H. W., \& Kleiner, B. M. (2001). Macroergonomics: An Introduction to Work System Design. Santa Monica: HFES.

http://umkm.jogjakota.go.id/direktori/index.php. (2013). Accessed April 1, 2013

Kawakami, T., Arphorn, S., \& Ujita, Y. (2006). Work Improvement for Safe Home; Action Manual 
for Improving safety, Health and Working Conditions of Home Workers. Bangkok: International Labour Office.

Michalska, J., \& Szewieczek, D. (2007). The 5S Methodology as a Tool for Improving the Organisation. Journal of of Achievements in Materials and Manufacturing Engineering, 24 (2), 211214.

Mitchell-Ketzes, S. (2003). Optimising Business Performance through Innovative Workplace Strategies. Journal of Facilities Management, 258-276.

Petrarolo, D. (1998). The 20 Keys to Workplace Improvement. Industrial Management, 40 (1), 2229.

Wibowo, R. (2012, May). Antara Globalisasi, UMKM di Jogja dan Internet. Accessed April 1, 2013, from http://www.wartapasarjogja.com/2012/05/ antara-globalisasi-umkm-di-jogja-daninternet/ 